\title{
Tiyatroya Rağmen Yaratıcı Drama
}

\author{
Inci SAN* \\ Ankara Üniversitesi
}

\begin{abstract}
Özet
Tiyatro, oyuncusu, yönetmeni, dramaturgu, sahnede ve sahne arkasindaki çalışanlarl ve çocuk, genç, yetişkin izleyicisi ile bir bütündür: Çalışanlart arastna son iki on yllda tiyatro pedagoglart da girmistir. Tiyatronun insanlart eğitmesinin mi daha önemli olduğu yoksa sanatsalltk ve estetiğin mi ön plana çıkarlmasl gerektiği tartısılla dursun, tiyatro pedagojisi (eğitbilimi) alan iki görüş̧in birleştiği bir alan olarak görülebilmektedir: Yaratıcilı̆gt ve grup çalışmasın ön plana alan yaratıcı drama çalışmalar ile tiyatronun karşt karşıya gelmesi de aslında söz konusu değildir: Önemli olan, dramacıların tiyatroyu daha fazla öğrenecekleri arasina almalarl, tiyatrocularn ise pedagojik bir eğitim sïrecinden geçmeye razı olarak, kendileri için yeni ufuklar açacak tiyatro eğitimbilimi alanina yönelmelerinin gereğini ve önemini benimsemeleridir. Dramanin bilimsel olarak nerelerde ve hangi yeni bilgilerle katısturlarak nasl kullanılacağının araștırlması, uygulanmast, yerleştirilmesi için, araştırma merkez velya da merkezlerinin kurulmasina hzla geçilmelidir:
\end{abstract}

Anahtar sözcükler: Drama, yaratıcı drama, tiyatro eğitbilimi

\begin{abstract}
Can we really mean that creative drama is a form versus theatre? Or should we emphasize creative drama as an essential way of learning, learning theatre, learning life and understanding what dramaltheater is standing for? For this approach the field "pedagojy of theatreldrama" should be studied. For doing this we need both the knowledge of theatre and all about creative drama. Pedagojy of theatreldrama is a wide field which after having studied and deepened in it can be easily a new profession in Turkey.
\end{abstract}

Keywords: Creative drama, theatre, pedagojy of theatre/drama

* Prof. Dr., Sanat Bilimcisi, incisan@hotmail.com 


\section{Giriş}

$\mathrm{Bu}$ yazı, üzerinde uzunca süredir durduğum tiyatro ile yaratıcı drama ilişkisi konusunda düşünce üretme aşamasında iken, Çağdaş Drama Derneği'nin İstanbul Şubesinden, düzenleyecekleri "Rağmen Toplantıları"mn ilk konuşmasının benden istenmesi üzerine oluşturduğum bir dizinin ilk ürünü gibidir. Kuşkusuz değerlendirilmesi, eleştirilmesi ve yeni düşünüler ve öneriler ile beslenmesi de dileğimdir.

Rağmen sözcüğü kimi Osmanlıca sözcükler gibi, güzel bir Türkçe karşılığı bulunmuş olsa da, yukardaki isim tamlamasına daha rahat oturmaktadır. Rağmen toplantılarının da ülkemizin içinde bulunduğu toplumsal - kültürel - moral ve etik durumlarla ilişkili olduğu kuşku götürmez. Sanatsal ve bilimsel kalkınma adına, şimdilik uzakmış gibi görünse de, yaratıcı dramanın geleceğine yönelik düşler görmek alışkanlığımı sürdüreceğe benziyorum.

\section{Tiyatro ile Yarattct Drama}

Tiyatro en genel anlamda, soyut, bileşik, örgütlenmiş, oyuncusu, yönetmeni, diğer tüm çalısanlarıyla ve çocuk, genç, yetişkin izleyicisiyle bir bütünü oluşturmaktadır. Bu kavram, Avrupa'nın pek çok ülkesinde ve her halde ABD'de de, tiyatro pedagoglarını da içerirken, ülkemizde şimdilik bu alanın sözü geçmemektedir. Kısaca, tiyatrodan söz edilirken tiyatro pedagojisi, tıpkı daha bir zaman öncesine dek dramaturginin de tanınmadığı gibi bilinmemektedir.

Bir eylem sanatları ve diğer pek çok sanat dalının birleşimi olan Tiyatro'da, kurum olarak, iç yönetim, fmans, mimari ve izleyiciyle buluşabilme vb. sayısız yan alan ve bunların taşıdığı sorunlar söz konusudur. İzleyici ile buluşma konusunda bile değişik yaş gruplarına ulaşma gibi önemli bir sorun yanında, bu alanda eğitimi mi (halk eğitimi, çocuğun eğitimi gibi), sanatsallığın ve estetiğin mi öne çıarılması gerektiği gibi, kültür politikaları ile ilgili çok önemli bir sorunsalla da yüz yüzedir. Gerçi bu sorunsal hemen tüm sanat dalları için de geçerlidir ama karmaşık, çok katmanlı yapısı nedeniyle tiyatro olgusunda bu sorunsal daha bir çetindir.

Sanatsallık ve estetik, tiyatrocuların bilgi ve görgüleriyle, tiyatro bilimi, sanatlar bilimi, estetik gibi konuları yakından ve sürekli izlemeleriyle orantılı olarak çözülebilir.

Peki eğitme işlevi bir yana bırakılabilir mi? Yani sanat için sanat gibi günümüzde oldukça boyutsuz kalmış bir slogan ile izleyicinin yaşantı, deneyim ve bilgilerinin artması, kısaca izleyici, yani toplum, yani toplum kültürü, kültür politikası gibi daha başka çabalar isteyen, bu anlamda kısaca yarara dönük bir yaklaşım günümüzde reddedilebilir mi?

Yeniden başa dönecek olursak, geniş kitlelerin hâlâ ne yazık ki incelikten, ince beğeniden, eleştirel ve yaratıcı düşünüden yoksun bırakıldığı ülkemizde akılcı bir kültür sanat politikasının gerekliliği söz konusu iken, bu olgunun eğitim ve eğitimbilime eğilmeden gerçekleşebileceği düşünülebilir mi?

Onun için tiyatro ile eğitim ve eğitimbilimini bağdaştıran, iç içe geçiren, tiyatro ile eğitim arasında bir aracı olan tiyatro eğitimbilimi, ülkemizde tüm gelişmiş ülkelerden daha da önemle gündeme gelmelidir. Oysa tiyatro oyuncusu, yönetmeni, hatta tiyatro bilimcileri bu alana hâlâ yabancıdırlar. Tiyatro pedagojisinin en önemli bileşeni olan yaratıcı drama ise neredeyse küçümsenen, çok basit bir olgu olarak anlaşılmaktadır bu kesimce. Öte yandan yaratıcı drama bir ders, bir disiplin, bir estetik eğitimi alanı olarak eğitim dizgemize yerleşmeye başlamıştır epeydir.

Onun için "Tiyatro'ya Rağmen Yaratıcı Drama" başlığını doğru okumak gerekir. Ülkemizde de "TIYYATRO ve YARATICI DRAMA ve TIYATRO PEDAGOJiSİ"nin bir konuşma başlığı ve bir kültür alanı olacağı gün kesinlikle gelecektir.

Dilerseniz şöyle bir şema yapalım:

Tiyatro'nun da Yaratıcı Dramanın da kaynağı OYUN'dur. 
Tablo 1

\section{OYUN}

Oyun yarara yöneliktir (Metin And)

Oynayan (ya da katllımcı) Açısından

\begin{tabular}{|c|c|}
\hline Tiyatro* & Yaratici Drama \\
\hline $\begin{array}{l}\text { 1) Sözcük olarak köken: theatron (yun.) } \\
\text { Anlamı: Seyirlik, seyirlik alan. } \\
\text { Özelliği: Yarar ve eğlenme. } \\
\text { Eylemlilik ve edilgenlik gösterenler } \\
\text { (oyuncular) ve gösterilenler (izleyenler) var. }\end{array}$ & $\begin{array}{l}\text { (Alm.: Spiel und Interaktion) } \\
\text { 1) Sözcük olarak köken: dran-dramenon (yun.) } \\
\text { Anlamu: eylem - eylemek, etmek, yapmak. } \\
\text { Özelliği: Etkin(lik), eylemlilik }\end{array}$ \\
\hline $\begin{array}{l}\text { 2) Önde gelen amaç } \\
\text { Sanatsallık-iyi oyun çıkarma (Edebîlik) }\end{array}$ & $\begin{array}{l}\text { 2) Önde gelen amaç } \\
\text { Paylaşım,birlikte is çkarma }\end{array}$ \\
\hline $\begin{array}{l}\text { 3) Ulaşılmak istenen } \\
\text { Üstün sanat - üstün sanat yapmak. } \\
\text { Bütünsel, tümleşik sanat- Gesamtkunstwerk }\end{array}$ & $\begin{array}{l}\text { 3) Ulaşılmak istenen } \\
\text { Duyular, imgeler, duygular, yaşantılar }\end{array}$ \\
\hline $\begin{array}{l}\text { 4) Aranan şey } \\
\text { Mükemmellik }\end{array}$ & $\begin{array}{l}\text { 4) Aranan şey } \\
\text { Yaratıcılık-kişisei ve ortaklaşmacı (kolektif) }\end{array}$ \\
\hline $\begin{array}{l}\text { 5) Elde edilmek istenen } \\
\text { Gösterinin parlaklığ } 1\end{array}$ & $\begin{array}{l}\text { 5) Elde edilmek istenen } \\
\text { Farkındalık-kendisi ve grupla ilişkili olarak }\end{array}$ \\
\hline $\begin{array}{l}\text { 6) Dayanılan öncelikli olgu } \\
\text { Teknik ve bilgi }\end{array}$ & $\begin{array}{l}\text { 6) Dayanılan öncelikli olgu } \\
\text { Deneyim(ler) }\end{array}$ \\
\hline $\begin{array}{l}\text { 7) Beklenen şey } \\
\text { Kendini kamitlama-star olma }\end{array}$ & $\begin{array}{l}\text { 7) Beklenen şey } \\
\text { Kendini yönetme-star olmama }\end{array}$ \\
\hline
\end{tabular}

\section{Ortak Paydalar}

8) Estetik haz, estetik yaşantı

9) Öğrenme-başlıca kendi oyunculuk becerisi ve tiyatroya ilişkin

10) Katharsis

11) Estetik ve niteliklilik
8) Estetik haz, estetik yaşantı

9) Öğrenme-kendine ilişkin ama daha cok sosyal öğrenme-toplumsallaşma

10) Katharsis

1I) Estetik ve niteliklilik

* Burada deneysel, araşırmacı, takım çalışmasına dayanan tiyatro oyunları dışındaki klasik-gelenekselleşmiş tiyatro anlayışına göre oyuncu yetiştiren kurumlara (bașta konservatuarlarımız olmak üzere) gönderme sözkonusudur.

Katılımcı (oyuncu) açısından iki alan arasındaki ayrımları ve ortak yanlan böylece vurguladıktan sonra üzerinde kısaca durmak istediğim bir konu şudur:

"Her okul bir tiyatro" sloganı ile 1996'larda başlayan okullararası tiyatro șenlikleri ki, aslında yarışmalar biçiminde gelişmiştir, tiyatro ile tanışma açısından her ne kadar olumlu görülebilirse de, tüm öğrenci kitlesini kapsayan bir eylem olmaması, kücük bir grubun tiyatro yapması, büyük çoğunluğun izleyici, yani edilgen ve belki de bir bakıma yoksun bırakılması, küçük grupta da starlașanların olması açısından, tam tümel bir etkinlik ve eylem olma niteliğinde değildir.
Buna karşılık, ilköğretim programlarında zorunlu seçmeli dersler arasına 1998-1999 öğretim yılında giren yaratıcı dramanın, sürekli olması ve ders niteliğinde olması dolayısıyla ciddiye alınma, getirdiği kazanımların gerek ögretmen gerekse veli açısından gözlenebilir olması dolayısıyla, kuşkusuz sosyal, fiziksel, psikolojik ve pedagojik yönlerden yararlar sağladığını söylemek yerinde olacaktır.

\section{Tìyatro Eğitimbilimi (Pedagojisi)}

Tiyatro Eğitimbilimine gelince, Batı dünyasinda 1960 'lardan bu yana sanatsal-estetik eğitimin, edebiyat ve tiyatro biliminin bir yan alanı olarak sosyal bilimler dünyasına giren bu 
araştırma ve uygulama alanı, hemen her ülkede, daha çok çeşitli aşamalarm öğretmenlerinin gereksinmesiyle yaygınlaşmaya başlamıştır denebilir. Tiyatronun halk eğitiminde kullanılışı çok daha eskilere dayanıyorsa da, eğitim dizgeleri içinde tiyatro/dramanın yer alması, 19. yüzyıldaki kimi denemelerden sonra 20. yüzyılda asıl gelişimini gerçekleştirmiştir.

1970'lerde özellikle çocuk, ergen ve gençlerin monotonlaşan, bilişsel yanı ağı basan öğretim programlarında yaratıcılığa, öğrenmekten haz almaya, kendi buluşlarnna ve araştırmalarına yer vermek adına zekânın duyusal, duygulu, estetik ve sosyal bölümlerini eyleme geçirmek için, tiyatro ve dramadan medet umuldu. Sanatlarm dans ve belki heykel çalışmaları dışında, kinestetik alana pek açılamayan niteliğine karşılık (resim, müzik vb.), drama tam bir "estetik eylemler sanatı" sunmaktaydı. Sözel yanıyla mantık, dil yetilerini; bedensel-fiziksel yamyla kinestetik yetileri; çizgi renk, tonlar, kokuların kullanımıyla eyleme geçen imgelem gücü ve imgelerin yaratılmasıyla, zihinlerin daha üretici ve eleştirel düşünmeye başladığı ileri sürüldü. $\mathrm{Bu}$, beyin araştırmalariyla da desteklendi, özellikle devinim içinde öğrenmenin küçük çocuk açısından önemi ortaya çıtı.

Önceleri okul-tiyatro ilişkisi ile başlayan eğilim, giderek yaratıcı drama çalışmalarıyla başkalaşmış, bu alanın özellikle çocuk ve ergenin, tiyatro temelinde ya da tiyatro teknikleri aracılığıyla kendini gerçekleştirmesi, sosyalleşmesi ve yaratıcı kılınması için önemsenmesine neden olmuştur. Giderek bu alanın bilimsellik kazandığını görmekteyiz. Öğretmenlerin bir ders işleme yöntemi olarak da benimsemesiyle yaratıcı drama ve uygulamalarının boyutlanmasina yol açılmusşır.

İki kurum, yani okul ile tiyatro arasındaki ilişkiyi ki, bu bir tür zorunluluktu, örgütlemek ve anlamlandırmak ise tiyatro pedagoklarmın çok sayıdaki işlerinden biri olmuştur. 1970'lerde birçok Avrupa ülkesinde tiyatroların okullara gitmesi, okullarda gösteriler düzenlemesi, ya da okul ile işbirliği içinde projeler geliştirmesi yanında İngiltere, Almanya gibi ülkelerde yaratıcı dramanın ders olarak programlara alınması aynı zamanlara rastlamıştır. Almanya'da halen yaratıcı drama ancak bazı eyaletlerde programdadır, ama kulüp çalışmaları biçiminde hemen her kesimde bir etkinlik olarak talep edilmekte ve yer almaktadır. Özellikle yetişkin ve yaşlı gruplarda kültür pedagokları ile tiyatro pedagoklan birlikte çalışmakta ya da çalışmaları yürüten kişi bu iki alanın talep ettiği nitelikleri kendinde toplamış olmaktadir.

Ayrıca, tiyatro pedagojisi, tiyatro sanatı ile iç içeliği dolayısıyla, profesyonel tiyatro insanının, yönetmenin, sahne ve kostüm tasarımcisının ve özellikle oyuncu-sanatçının yetişmesini de sağlayabilmektedir (Simhandl, 1986, s. 949).

Tiyatro pedagojisi, anlaşılacağı üzere yalnızca sanatsal bir çalışma alanı olmayıp pedagojik (eğitimbilimsel) bir çalışma alanıdır da. Genel anlamda, "profesyonel olmayanlara da sanatsal anlatım biçimleri kazandırmak" (Hendricks, 2004, s.37) için aracı olan bir alan diyebiliriz.

Tiyatro pedagojisinin uygulama çalışmaları yaratıcı drama çalışmalarıdır. Bedene dönük, imgesel ve simgeselliği, yaşantı zenginliğini, anlatım I (ifadeyi) yüreklendirecek yaratıcı süreçlerden oluşur. Sözel olmayan iletişim çalışmaları ile sözel olanları içeren çalışmalar, "belirsiz ya da yinelenmiş iletiler gibi iletişim yanlışlıklarm düzeltmeye yöneliktir, bunun için belli bir duyarlılık edinilir. Bu çalışmalar ile her meslekteki kişi, daha adlandırılmamış ama belki de daha önemli olabilecek iletişimsel etkenleri fark etmeye ve anlamaya; vereceği tepkileri denileștirip ilişkileri daha kapsamlı olarak meslek yaşamındaki yaşantı ve eylemlerinde anlamlandırıp kullanabilecek yetenekler kazanır (Hendricks, 2004, s.37-38).

\section{Tiyatro Pedagogu Kindir?}

Tiyatro eğitimbilimcisi sosyal calıșmacı değildir; tiyatro pedagogu psikolog, okuldaki psikolojik danıssman ya da rehber değildir; terapist, sanat eğitimcisi, yardimcı ögrretmen de değildir.

Tiyatro pedagogu, Miriam Walter'e göre, "pedagoji okumuş ya da pedagoji ile ilişki kurmuş tiyatro sanatçısıdır... Tiyatro alanında eğitim 
almamışlara oyunculuk öğretmek için reçeteler sunan kişi olmayıp sanat sunan kişidir." (Walter, 2004, s.6).

Eğitimbilimciler ve tiyatro / drama ile ilişki kurmuş ögretmenler ise, anlaşılacağı gibi, dramayı çeşitli öğrenme alanları için (sanatsal öğrenme, bilgisel öğrenme, dilsel öğrenme, sosyal ögrenme [toplumsallaşma] vb. gibi) aracı olarak görürler. Her şeyden önce pedagogdurlar, bu şapkadan vazgeçemezler, tıpkı tiyatro kökenli tiyatro pedagoglarının tiyatro'dan vazgeçemeyecekleri gibi.

\section{Tiyatro Pedagogu Hangi İşleri Yapar?}

Burada tiyatro pedagoglarını sınıflara ayırmak gerekebilir: (Doğal olarak bu sınıflama tiyatro pedagojisinin bir meslek ve bilimsel bir alan olarak kabul edildiği ülkeler için geçerlidir)

\section{Tiyatrolarda görev yapan tiyatro pedagoglarl}

\section{a. Yetişkin Tiyatrosunda}

İzleyici dramaturgisi, izleyici yönetimi, (Bugün seyircinin de oyuncu kadar etkin olduğu kabul ediliyor)

Pazarlama işlerini görme,

Öğretmen temsilcisi,

Çocuk eğlendiricisi

Sanatçı

gibi alt kimliklere bürünen bu meslek insanları şöyle tanımlanabilirler: Uygun eşlik-programları ve projeler aracılığıyla tiyatro kurumunu geniş bir kitleye tanışık kılmak; bir sanat biçimi (dalı) olarak tiyatro'ya yakınlaşmayı sağlamak; özellikle genç insanları, çocukları "bugünün seyircisi" olarak ciddiye alma ve böylece gelecekteki izleyiciyi de uzun süremde tiyatro evine bağlamak; estetik deneyimlerin kazanılmasını sağlamak; yuva çocugundan en yaşlı insanlara dek geniş kitleye tiyatro bilimi-bilgileri ve sahne deneyimi, estetik yaşantı edindirmek; eleştirel seyirci yetiştirmek; kültürel birikimi artırmak; böylece tiyatro'nun geleceğini de sağlama bağlamak (Walter, 2004, s.6).

\section{b. Çocuk Tiyatrosunda}

Özetleyecek olursak, beş çalışma alanı saptanabilir:

1. Sahnelemelerin öncesi ve sonrasının hazırlık çalışmaları

2. Tiyatro ve okul arasındaki aracılık çalışmaları

3. Seyirci hizmeti olarak yapılan çalışmalar

4. Çocuk ve ergenlerle yapılan tiyatro / drama çalışmaları

5. Alımlama araştırması çalışmaları - seyirci ve prodüksiyon hakkında çalışmalar ("seyir yerinin dramaturgluğu (dramaturgisi)" (Schneider, s. 86-87).

\section{Eğitim alantnda görev yapan tiyatro pedagoglart}

Burada bir anımsatma olarak şu alıntıya yer vermek isterim:

"Eğitim, çocuk ve gençlerin kendilerini gerçekleştirmesine, özgürleşmesine, anlatım ve iletişim yeterliliği kazanmasına, diğer insanları anlamasına ve iyi ilişkiler kurmasına, sağlıklı ve üretken olmasına, araştırma, öğrenme ve sorun çözme yeterliliği kazanmasına yardımcı olmalıdır. Eğitim insanı, kendine, insanlığa ve edindiği bilgiye yabancılaştırmamalı; onun toplumsal ilişkiler içinde yerini ve konumunu almasına olanak tanımalıdır. Öğrenenlere, hiçbir ayrım yapılmadan yeteneklerini yeterliliklere dönüştürecek eğitimsel yaşantılar summalıdır." (Başaran, 1996, s.104).

Tanımlanan eğitim kuşkusuz ideal bir eğitimdir. Cumhuriyetin ilk dönemlerinde gerçekleştirilmesi ilkelere bağlanmış ulusal bir eğitimimiz vardı. Ögrretmenleriyle, velileri, okul yöneticileri ve eğitim denetçileri ile bu ilkelere uyulduğunu biliyoruz. Okullar ve halkevleri gibi kurumlar örgün ve yaygın eğitimde sanatları, kültürü, tiyatroyu da hiç ihmal etmeden insanlarımızın yaşamına sokmaya uğraşıyorlardı. Bu ilkeli durum eğer sürebilseydi bugün daha sağlam kültür ve eğitim politikalarına sahip olunurdu. 


\section{a. Okul-Tiyatro İlişkisi}

Yukarıdaki bağlamda bir eğitim için sanatlar eğitiminin ve yaratıcı dramanın önemini vurgulamaya gerek yoktur. Gene bu bağlamda olmak üzere tiyatro pedagogunun aşağıdaki görevleri vardir:

Okul ve tiyatro arasındaki bağı kurar. Bir tiyatro oyununu seyredecek öğrencilerle, söz konusu oyuna hazırlayıcı çalışmalar yapar. Oyundan sonrasını da düzenler. Oyun hakkında söyleşiler, dü- șünce alışverişleri ve eleştirilerin akışını yönetir. Çeşitli tiyatrolara gidişleri ayarlarken, provaların da izlenmesini, kulisin ve yapının diğer yerlerinin ziyaret edilmesini, mümkünse yönetmen ve oyuncular ve diğer sahne ve arkasında çalışanlarla, öğrencilerin tanışıp söyleşmesini sağlar. Bu gibi ziyaretlere öğretmen, okul yöneticisi ve velilerin de zaman zaman katılabilmelerini gözetir.

Öğrencilerin tiyatro / drama temelli projeler, programlar yapmalarına; tiyatro / dramanın tüm sanatları içeren ve bazen de okunan derslerin bir çoğu ile ilişkili olan ya da müze ziyaretleri için, "eğitim-öğretim ve drama projeleri" hazırlamalarına yardım eder. Okulda tiyatro ya da drama gösterimleri düzenlenmesinde rol oynar. Öğretmenlerin tiyatro / drama alanında hizmet içi eğitim almalarında öğretici olarak veya yetkili kurumlarla ilişkiye girerek görev alır. Bu kurumların üniversite ve fakültelerindeki ilgili birimler ve tiyatro pedagojisi merkezleri olmasi gerekir.

Burada önemli olan yaratıcı drama eğitimi almamış, tiyatro bilgisinden yoksun ve yeteneksiz kimi ögretmenlerin devreye girmesinin önlenmesidir. (Jerofke, 2004, s.16) Bu, öğrencilerin tiyatro zevkini de öldürür.

Bizdeki uygulamada Türkçe öğretmenlerinin ya da beden eğitimi veya resim-müzik öğretmenlerinin devreye sokulması söz konusu olmuş, yalan yanlış oyun seçimleri yapılagelmiştir. Öğrenciler kendi metinlerini bir uzman yardımıyla yazabilselerdi, kim bilir ne ilginç sonuçlara varilabilirdi.

\section{b. Yaygın eğitimde tiyatro pedagogu}

$\mathrm{Bu}$ madde altına rahatlıkla "seyircinin eğitilmesi" alt başlığı koyulabilir. Velilerin, eğitimle ilgili her kuruluş ve örgütün yararlanabileceği alan olarak tiyatro / dramayı gene bu kuruluşlara anlatabilecek olan tiyatro pedagogudur. Kültür merkezleri, gençlik evleri ya da kulüpleri, spor kulüpleri, yalnız tiyatroyu anlama açısından değil, ilişkilerin biçimlenmesinde bir niteliklilik sağlaması bakımından da drama eğitimine gerek görmelidir.

$\mathrm{Bu}$ kuruluşlara, fuarları, büyük sergiler ve müzelerdeki etkinlikleri, çeşitli işletmelerdeki insan ilişkileri açısından değişik meslek odaları ve dernekleri de katmak gerekir. Bir işletmenin verimini artırmak, pazarlamada, telefon konuşmalarında, değişiklik yönetimlerinde, ekip çalışmalarında, personel eğitiminden, bir konferansta veya kongrede konuşma yapmaya dek, tiyatro pedagojisi olumlu roller üstlenir.

Görüldüğü gibi tiyatro pedagojisi yalnızca okulla tiyatronun kesiştiği yerde değildir; bağımsız bir sanatsal pedagojik disiplindir, ayrı bir meslektir. Onun için artık Okul ve Tiyatro, ya da Eğitim ve Tiyatro değil, başlık "Tiyatro-Tiyatro Eğitimbilimi ve Okul" olmalıdır (Jerofke, 2004, s.16).

Tam da burada ülkemiz açısından şu iki önemli soruyu sormalıyı:

1- Tiyatro, eğitimi önemseyecek midir?

2- Eğitim, klasik (ezberci-tekdüze...) eğitim dizgesini terk edip, memurluk zihniyetinden kurtularak yeni yolları deneyecek midir?

Gözlem yapma, dünyayı alımlama ve yansıtma, imgelerle düşünme, sözel olmayan anlatımda yeterlilik, imge dili, simge ve göstergeleri anlama gibi yeti ve yeteneklerin geliştirilmesi eğitim dizgemizde yer alıyor mu? Sanatların diline, sanatsal öğrenmeye yer var mı?

Yeni atılımlar yapılmıyor değil. Alternatif eğitim, pozitif eğitim, interaktif eğitim kavramlarını duyuyoruz. Ancak, hiç birinde açık seçik sanat, sanatla eğitim, sanat eğitimbilimi, müzik eğitimbilimi, tiyatro/drama eğitimbilimi, dans eğitimbilimi $\mathrm{vb}$. kavramlarının geçtiğine tanık olmuyoruz. Bilişsel ve duyuşsal yanlarıyla sanatın tümel bir öğrenme sağladığına ilişkin açık ve net bir açıklama da duymuyoruz. Hatta bizzat 
çeşitli dalların sanatçılarının da bilgi ve bilime ve günümüzdeki ilerlemiş beyin bilimine dayalı olarak sanatla öğrenme savı ile karşımıza çıkmadıkları da bir gerçektir.

\section{Türkiye'de Tiyatro Pedagojisi Var me?}

Tiyatro pedagogunun yetiştirileceği özel eğitim - öğretim programlarının alan bilgisi, genel kültür bilgileri ve uygulama bilgilerini kapsaması gerektiği açıktır.

Yaratıcı drama da başlı başına bir disiplin olup hem kavramsal hem uygulama bilgilerini içerdiğine göre, tiyatro pedagojisi alanı için öğrenim programları olarak, yaratıcı drama programlarının ileri aşamalarının örnek verilmesi mümkündür. $\mathrm{Bu}$ durumda, Ankara Üniversitesi Eğitim Bilimleri Fakültesindeki "Yaratıcı Drama" Tezsiz ve Tezli yüksek lisans programları ile; aynı üniversitenin Dil ve Tarih-Coğrafya Fakültesi Tiyatro Bölümünün "Çocuk Tiyatrosu, Oyun ve Drama" başlıklı tezli yüksek lisans programı ve her ikisine de eklenmesinde yarar sağlayacak olan doktora düzeyi çalışmaları, şimdi ve ilerisi için uygun programlardır (Bkz.: 6. Ulusal Drama Semineri Yayını, özellikle s. 105-142).

Eğitim Bilimleri Fakültesinin programına daha çok tiyatro bilimi, tiyatro türleri, sahne ve sahne arkası tiyatro süreçleri ve oyunculuk derslerinin koyulması; Dil ve Tarih - Coğrafya Fakültesindeki programa da daha çok eğitimbilim ve genel kültür dersleri (sanat tarihi, sanat felsefesi, sanat pedagojisi, sanat psikolojisi, sanat sosyolojisi, estetik vb.) koyulmasi; hatta her iki programda seçmeli olarak işletme hukuku, halkla ilişkiler, toplumbilim, sosyal psikoloji vb. tiyatro yönetimiyle ve insan ilişkileriyle ilgili derslerin yer alması öngörülebilmelidir.

İki programın da içinde yer aldıkları fakülte açısından, birinin daha çok eğitime, diğerinin de daha çok tiyatro alanına eğilimli olmaları ise doğaları gereğidir.

Çağdaş Drama Derneği'nin Yaratıcı Drama Liderliği programı, son biçimiyle 420 saatlik bir sürede ve altı aşamada verilmektedir. Eğitim Bilimleri Fakültesinin yüksek lisans programı konseptinde oluşan program kuşkusuz daha uzun süreli olması açısından dikkat çekicidir. Oluşum
Drama Stüdyo ve Atelyesinin programı iki yıllık süre için oldukça zengin içeriklidir. Dil ve Tarih Coğrafya Fakültesi'nin yüksek lisans programinın temel hedefinin "okulda ya da okul dışında oyun ve tiyatro ilişkileri yürütebilecek, teknikleri kullanabilecek, oyunun ve tiyatronun olanaklarını kullanabilecek.... liderler yetiştirmek" olduğu belirtilmektedir. Okul tiyatrosunun belirli bir düzeyin üzerine çıkartılabilmesi ve çocuk tiyatrosu için çocuk oyunu üretebilecek, okulla eşgüdümlü olarak oyun yönetilmesi üzerinde çalışabilecek elemanlar yetiştirme amacı da vurgulanmaktadir. Tiyatro pedagojisi ile ilintili bu doğrultulardaki çalışmalar bu alanın ülkemizde artık tanınacağına ilişkin bir kanıttır (6. Ulusal Drama Semineri Yayın1, s. 128'de Dr.Kadir Çevik'in düşünceleri).

Tiyatro pedagogu nasıl yetişmelidir? sorusuna yanıtlar, sözü geçen "6. Ulusal Drama SemineriDrama Liderliği" başlıklı yayından, en azından ülkemizdeki düzeyi, ki bu düzey epeyce gelişmiş bir düzeydir, ögrenmek açısından salık verilir (İstanbul'daki kimi tiyatro çalışmalarında bu alanın işin içine girip girmediğini tam olarak saptayamadım.).

Bilgisel açıdan ve asıl, çalışma alanı (istihdam alanı) olarak tiyatro pedagojisinin geliştirilmesi ise her halde önümüzdeki yıllarda gerçekleşecektir. Özellikle yaratıcı drama ile tiyatro'nun arasında kurulacak sağlam ve bilgiye dayalı bağ ile tiyatronun da başka niteliklere kavuşabileceği ve yazımızın başındaki özellikler listesinde yer alan kimi ayrımların en azından bu denli keskin olmayacağını, diğer ülkelerdeki çocuk tiyatrosu ve tiyatro alanındaki çalışmalara da bakarak, öngörmek güç değildir.

\section{Sonuç}

Türkiye'de yaratıcı drama alanında şu anda yapılanlara bakarak nelerin gerçekleştiğini saptayalım:

Yaratıcı drama yoluyla katılımciları oynamaya teşvik etmek ve onların kendi içlerindeki oyuncuyu keşfetmelerini sağlamak;

Katılımcının giderek bu oyunlar içinde kendine ilişkin yeni, yaratıcı yeti ve 
yetenekler bulmasına yardımci olmak (rol oynama, resim yapma, metin yazma, renklerle, maskelerle uğraşma ve imgeler yaratma , vb. gibi);

Öğretmen gruplarının, çocuk ve gençlere ulaşmaları ve iletişim kurmalarında daha yeterli olma, onların yeni bilgileri edinme, iyi bir Türkçenin yazılması ve söylenmesi kazanımlarını edinmelerinde onlara kılavuzluk yapabilme;

Onlar gibi oynayan, koşan, düşünüp tartışan bir kişi olarak öğretmenin öğrenciye yabancılaşmasımı ortadan kaldırma;

Insanların kendilerini gerçekleştirme, kimi fantezilerini işe koşma, mutlu ve hoşnut olmalarına yol açma, kısmen de yaşantılarından estetik bir haz alabilmelerini sağlama;

- Bu arada eğitim-öğretimde bir yöntem olarak kullanılmasını sağlama.

Tüm bunlar oyun'un gizil gücü ile ilişkilidir kuşkusuz. Kuramsal boyutta yapılanları ise, katılımcılar açısından şöyle özetlemek olanaklıdır: Katılınan grup yaşantılarının ve deneyimlerin, edinilen bilgilerin, belli okumalara da dayan-dırılarak, deneme yazısı, proje ya da tez olarak, belli sınırlar içinde geliştirilmesi.

Şimdi artık, farkında olunan yaratıcı dramanın gizil gücünün, daha bilimsel olarak nerelerde ve hangi yeni bilgilerle katıştırılarak nasıl kullanılacağının araştırılması, denenmesi, yerleştirilmesi gibi daha ileri düzlemlere tassınması gerekliliği söz konusudur.

İşe eğitim-öğretim alanı ile birlikte ele alınacak tiyatro pedagojisi, müze pedagojisi ve özellikle cocuk tiyatrosu bağlamlarında başlamakta, ülkemiz eğitim sistemi açısından büyük yararlar vardır. Kuşkusuz yaratıcı drama alanı önümüzde çok yeni ufuklar açmıştır. Bunlardan yararlanmamız gerekmektedir. Bu bağlamda akla ilk gelen birkaç öneri şunlar olabilir:

\section{Somut Öneriler}

1. Yaratıcı Drama Araştırma Uygulama Merkezi açılmalıdır.

2. Tezsiz ve Tezli Yaratıcı Drama Yüksek Lisans Programı "Tiyatro/Yaratıcı Drama Eğitimbilimi" adını alarak

a. Çocuk tiyatrosu ile ilgili tiyatro pedagogu

b. Genelde tiyatro ile ilgili tiyatro pedagogu yetiştirmelidir.

Böyle bir program, hatta bir Anabilim Dalı, en çok Eğitim Bilimleri Enstitüsüne ya da Ankara Üniversitesi Sosyal Bilimler Enstitüsüne yaraşır. Böyle bir araştırma ve uygulama alanı, tiyatro bilimine ve tiyatro alanına da büyük katkı sağlar. Dramaturgluk yanında tiyatro pedagogları da istihdam edilmeye başlanır. (Diplomalı işsizler sorununa da bir ölçüde çözüm getirilmiş olur).

3. Tiyatrolarda tiyatro pedagojisi bölümleri açılmalıdır.

\section{Kaynaklar}

Aslan, N. (editör) (2004). Drama Liderliği, Türkiye 6. Drama Liderleri Buluşması ve Ulusal Drama Semineri, Oluşum Yayınları No: 8, Ankara

Başaran, I. E. (1996): Eğitime Girişs. Ankara

Hendricks, M. (2004). Von der Supervision zur Sozialen Kulturarbeit - Theaterpädagogik in Theorie und Ausbildung in: Korrespondenzen, Tiyatro Pedagojisi Dergisi, Heft 45, s. 37-39 Hannover

Jerofke, B. (2004). Theaterpädagogik am Theater als Schnittstelle zwischen Theater und Schule. Korrespondenzen, Heft 45, s.15-16 Hannover

Schneider, W. (2005). Çocuklar İ̧̧in Tiyatro, (Çev.: Ayșe Selen), İstanbul: Mitos-Boyut Yaymları

Simhandl, P. (1986). Theaterpädagogik Theaterlexikon, Rowohltsenzyklopädie, Reinbek bei Hamburg, s. 948-950

Walter, M. (2004). Der Kampf Kommunikativer Künstler um künstlerisehe Anerkennung Korrespondenzen, 45, 6-7 


\title{
Darstellendes Spiel (Praktischer Teil der Theaterpädagogik) versus Theater?
}

\author{
İnci SAN* \\ Ankara Universität
}

Theater als endlos expansive Institution besteht aus Elementen wie Spielern, Regisseuren, Zuschauern, Bühnenbildern und vielen anderen vor udg. hinter der Kulisse, Musikern, Musizierenden und Theater ist eine ganzheitliche Organisation. Die Zuschauer muss man in mehrere Kategorien einteilen, wie Kleinkinder, Jugendliche und Erwachsene. Seit den $70^{\prime}$ er Jahren kommen hierzu noch die Theaterpädagogen, genau wie die Dramaturgen, die aber schon früher an den Theatern fungiert haben.

Theater, gesehen als ein Gesamtkunstwerk, hat noch Probleme wie Verwaltung, Finanzen, geeignete Architektur und Kommunikation mit den Zuschauern.

Eine weitere Frage wäre, ob Theater die Pädagogik (Kinder und Erwachsenenerziehung) an der ersten Stelle sehen oder das Künstlerische und $\ddot{A}$ sthetik in den Vordergrund stellen will.

Das Künstlerische kann durch Verfolgen und Verinnerlichung der Theaterwissenschaft, Kunstwissenschaft und Ästhetik (meistens theoretisch) besser entwickelt werden. Aber wie soll Pädagogik gelernt werden? Kann man ohne erziehungswissenschaftliche Kenntnisse Theater, insbesondere Kindertheater machen?
In der Türkei, wie sollte man kreative, kritische und produktive Kinder und Jugendliche heranziehen, da das Land mit so vielen sozialen, kulturellen, moralischen, ethischen Problemen besonders konfrontiert ist? Es steht leider fest, dass die Schule nicht mehr ausreicht und für die Schüler nicht mehr attraktiv genug ist. Dieses Problem kann nur durch rationale und zeitgenössische Lern- und Lehrpläne und viele künstlerische und kulturelle in- und außerschulische Nebenaktivitäten gelöst werden.

Unter diesen Aktivitäten nehmen theatralische / dramatische Arbeiten eine sehr effektive und wichtige Rolle ein. Gerade an dieser Stelle ist Theaterpädagogik ein extrem wichtiges Mittel. Sie verbindet Pädagogik mit Theater / Drama und die Praxis besteht aus kreativem Drama (Drama in Education-Darstellendes Spiel), was in der Türkei seit 1998 in den Grundschulen von 4. bis 8. Klassen ein Wahlpflichtfach ist. In den Kindergärten (Vorschulalter) und in den sogenannten Mutterklassen (für Kinder von 5 bis 6 Jahren) existiert darstellendes Spiel seit vielen Jahren.

Wenn wir nach dem Wesen des Theaters und des Darstellenden Spiels schauen, können wir in dem folgenden Vergleich unterschiedliche

*Prof. Dr., Kunstwissenschaftlerin, incisan@hotmail.com 
Tablo 1

SPIEL

(, Spiel ist pragmatisch ,-Metin And)

Dieser Vergleich ist von dem Standpunkt des Spielers / des Teilnehmers durchgefuhrt werden.

\begin{tabular}{ll}
\hline Theater $\left(^{*}\right)$ & $\begin{array}{l}\text { Darstellendes Spiel } \\
\text { Spiel unda Interaktion (W.Nickel) }\end{array}$ \\
\hline Ursprung: theatron (griechisch) & $\begin{array}{c}\text { Ursprung: dran, dramenon (gr.) } \\
\text { dt. handeln, tun, üben }\end{array}$ \\
dt. zuschauen; Aufführungsort & $\begin{array}{l}\text { Haupteigenschaft: Tätigkeit, Aktivität } \\
\text { Haupteigenschaft: Nützlichkeit }\end{array}$ \\
Hauptziel: ästhetisches/und erfolgreiches Spielen & $\begin{array}{l}\text { Hauptziel: zusammen arbeiten, miteinander Teilen } \\
\text { Endziel: Sinne, Vorstellungen, Gefühle, Erlebnisse, }\end{array}$ \\
Endziel: Erhabene Kunst darstellen & Erfahrungen erkennen \\
Erstrebenswertes: Perfektion & Erstrebenswertes: Kreativität, persönlich und kollektiv \\
Was man erreichen will: prachtvolle Performance & Was man erreichen will: Selbstfindung, Selbsterkenntnis, per- \\
Prämisse: Spieltechniken und -kenntnisse & sönlich und als Gruppe \\
Erwartung: sich selbstbeweisen, zum Star werden & Prämisse: Erfahrungen, Erinnerungen \\
& Erwartung: Selbstkontrolle, Nicht zum Star werden, Erzählen \\
& können
\end{tabular}

Gemeinsame Nenner

Ästhetischer Genuss, ästhetische Erlebnisse

LERNEN - besonders über eigene Spielkunst und -fähigkeit, über das Theater

KATHARSIS Ästhetisierung und Qualität
Ästhetischer Genuss, ästhetische Erlebnisse

LERNEN- uber sich selbst, aber viel mehr soziales Lernen

KATHARSIS Ästhetisierung und Qualität

* Dieser Vergleich gilt natürlich nur für das klassische, traditionalisierte Theater und für die Institutionen, die nur Spieler mit dieser Mentalität ausbilden

Merkmale und gemeinsame Nenner finden:

\section{Was will oder kann Theaterpädagogik bewirken?}

Dieses expansive und fast grenzenlose Berufsfeld, was in der Türkei noch nicht richtig bekannt und deswegen auch nicht anerkannt ist, könnte auf jeden Fall als eine Koordinationsstelle zwischen Theater und Schule fungieren.

Obwohl es als Berufsfeld noch nicht definiert ist, ist Darstellendes Spiel als ein Wahlpflichtfach seit 1998 in den Schulen in die Lehrprogramme aufgenommen worden. Es gibt leider noch nicht genügend Lehrkräfte für diesen Unterricht, da Darstellendes Spiel oder Kreatives Drama eben noch nicht definiert ist. Der Unterricht wird meistens von Lehrern/innen außerhalb der Schule gegeben oder von Fachlehrer/innen, die an mehreren Kursen des „Kreativen Drama Vereins“ oder an manchen Kursen von gleichwertig gestellten anderen Vereinen teilgenommen haben.
Der Verein des Kreativen Dramas ist zwar noch nicht von dem Erziehungsministerium offiziel anerkannt, ist aber seit Jahren dem Ministerium bekannt, was auch eine Anerkennung bedeutet.

Wenn Schauspieler und Theaterleute Interesse zeigen, nehmen sie manchmal an diesen obengenannten Kursen teil. Die Kursprogramme von ernsthaften Vereinen enthalten auch pädagogische Inhalte. Theaterpädagoik könnte viel mehr Theaterleute mit Dramalehrer/innen zusammenbringen.

Die Lehrenden, die an Theaterabteilungen oder Konservatorien Schauspieler/innen ausbilden und auch die Lehrer/innen für kreatives Drama könnte man Theaterpädagogen nennen. Aber eigentlich muss ein Theaterpädagoge mit weiteren Kenntnissen in der Bereichen Kunst und Kunstgeschichte, insbesondere zeitgenossische Kunst, Kunsterziehung und - pädagogik, Musik, Psychologie, insbesondere Entwicklungspsycho- 
logie, aber auch Tiefenpsychologie, Soziologie und im weiteren Verwaltungswesen, Kommunikation, Museumspädagogik, Ästhetik udg. ausgerüstet sein.

Auf der anderen Seite, wie Miriam Walter feststellte, sind Theaterpädagogen „keine Sozialarbeiter, keine Psychologen, keine Schulpädagogen, Therapeuten, Kunsterzieher oder Aushilfslehrerkräfte" ( Korrespondenzen, Nr. 45, S. 6). Walter meint weiter, ein Theaterpädagoge ist „ein Theaterkünstler mit pädagogischer Note, mit einem Hauch pädagogischen Anstrich.... Er tischt keine Schauspielschulersatzrezepte auf. Er macht Kunst.

Dagegen würde eine Lehrerin für kreatives Drama meinen, dass Drama ein wunderbares Mittel für verschiedene Lernarten wie künstlerisches Lernen, kognitives Lernen, Sprachelernen, soziales Lernen, udg. 1st. Für diese Lehrkräfte ist Theaterpädagogik in erster Linie ein erzieherisches Mittel.

So oder so, ein Theaterpädagoge ist einer, der sich multidisziplinär ausgebildet hat. Er muss sich auch immer weiterbilden wie Erziehungswissenschaft und aber auch Theaterwissenschaft sowieso verlangt.

Eben deshalb müssen die Lehrprogramme für kreatives Drama weiter entwickelt werden. Im Moment existiert als Masterprogramm an Ankara Universität, Fakultät für Erziehungswissenschaften, ein 2 jähriges Programm zusätzlich Masterabschluss. Von derselben Universität, Fakultät für Sprache, Geschichte und Geographie besteht die Möglichkeit, innerhalb des theaterwissenschaftlichen Masterprogramms Kreatives Drama auch als Masterabschluss akzeptiert wird. Den beiden Programmen müssen die fehlenden Wissensbereiche hinzugefügt werden, wie Kunst, Philosophie, Soziologie und Psychologie, bere- ichert mit Verwaltungsjura, Kommunikationskunde udg.

Nach diesen Abschlüssen wäre ein Theaterpädagoge voll ausgerüstet, um $\mathrm{zu}$ verwirklichen, dass Theater/Spiel eine Bildungs-, Freizeitsunterhaltungs-und Kunstmultiplikationstätigkeiten wird. Damit wird eine hinreichende Vermittlung von Theaterwissen und Bühnenerfahrung für die vom Kindergarten bis hohe Alter ermöglicht. Der Theaterpädagoge wird dann besser in der Lage sein, „kulturelle Erfahrungsschatz zu erweitern, ästhetischen Erlebnisraum zu schaffen und Theater für die Zukunft zu sichern". Er kann weiterhin "soziale Kompetenzen mit Theater und Spiel fördern" und somit besseres Kindertheater fördern. Vor allem kann er den teilnehmenden Zuschauern und das Publikum kritisches, produktives und kreatives Denken vermitteln. (Zitaten von Walter, S. 6-7 und ähnliche Gedanken bei W. Schneider, S. 86-87)

\section{Perspektiven}

Zum Schluss möchte ich drei Vorschläge unterbreiten:

1. Ein Zentrum für Forschung und Praxis für Kreatives Drama muss gegründet werden. Dieses Zentrum wird.

Publikation und / auch Übersetzungen realisieren.

2. Der Titel des Masterprogramms an der Universität Ankara muss „ Programm für Pädagogik des Theaters/Dramas(Spiels)“ heißen. Durch dieses Programm ausgebildete Kräfte sollen in den Schulen und auch an Theatern angestellt werden. Eine Definition von diesem Bereich muss vorbereitet werden.

3. An den Theatern sollen Abteilungen für Theaterpädagogik eröffnet werden. 
